\title{
PENGARUH EFIKASI DIRI DAN INTERNAL LOCUS OF CONTROL TERHADAP PERENCANAAN KARIR MAHASISWA PRODI BIMBINGAN DAN KONSELING IKIP PGRI MADIUN
}

\author{
Tyas Martika Anggriana*, \\ tyas.ma@gmail.com \\ Asroful Kadafi*, \\ asrafulkhadafi@yahoo.co.id \\ Rischa Pramudia Trisnani* \\ rischa_pramudia@yahoo.com
}

\begin{abstract}
ABSTRAK
Perancanaan karier adalah kecakapan atau kesanggupan siswa dalam menentukan langkah yang akan dilakukan dalam karier untuk mencapai tujuan yang telah ditetapkan sesuai dengan kemampuan dan persyaratan yang meliputi pengetahuan dan pemahaman akan diri sendiri, pengetahuan dan pemahaman akan pekerjaan, serta penggunaan penalaran yang benar antara diri sendiri dan dunia kerja. Perencanaan karir individu dipengaruhi oleh beberapa faktor, diantaranya adalah efikasi diri dan internal locus of control internal. Tujuan dari penelitian ini adalah untuk mengetahui apakah ada hubungan positif antara efikasi diri dan internal locus of control terhadap perencanan karir mahasiswa Prodi Bimbingan dan Konseling IKIP PGRI Madiun.

Penelitian ini menggunakan metode expost-facto. Populasi dalam penelitian ini adalah mahasiswa Prodi Bimbingan dan Konseling IKIP PGRI Madiun sebanyak 459 mahasiswa. Dari jumlah populasi sebanyak 459 mahasiswa diambil sampel sebanyak 210 mahasiswa. Sampel penelitian diambil 210 mahasiswa diambil secara acak. Instrumen pengumpulan data menggunakan skala psikologi, sedangkan analisis data menggunakan teknik regresi ganda.

Berdasarkan analisis data penelitian diperoleh hasil 1) tidak ada pengaruh signifikan efikasi diri terhadap perencanaan karier mahasiswa Prodi Bimbingan dan Konseling IKIP PGRI Madiun, 2) ada pengaruh signifikan internal locus of control terhadap perencanaan karier mahasiswa Prodi Bimbingan dan Konseling IKIP PGRI Madiun, 3) ada pengaruh simultan efikasi diri dan internal locus of control terhadap perencanaan karier mahasiswa Prodi Bimbingan dan Konseling IKIP PGRI Madiun.
\end{abstract}

Kata Kunci: Efikasi Diri, Internal Locus of Control, Perencanaan karir

*Tyas Martika A, Rischa Pramudia T, dan Asroful Kadafi adalah Dosen Program Studi Bimbingan dan Konseling Fakultas Ilmu Pendidikan IKIP PGRI MADIUN. 


\section{Pendahuluan}

Setiap orang memerlukan lapangan kerja untuk bekerja. Di masyarakat terdapat berbagai jenis pekerjaan. Setiap individu mempunyai kebebasan untuk memilih suatu karier atau pekerjaan serta pandangan hidup ke depannya yang diikuti oleh tanggung jawab. Data yang diperoleh dari Badan Pusat Statistik (BPS) menunjukan jumlah pengangguran di Indonesia pada bulan Agustus 2014 sebanyak 7,24 juta jiwa. Jika dibandingkan dengan data bulan Februari 2014, jumlah pengangguran di Indonesai naik sebanyak 90.000 jiwa (kompas, 2014). Jumlah pengangguran ini jika dibiarkan akan menimbulkan permasalahan.

Karier sering kali disamakan dengan pekerjaan. Perencanaan karier disamakan dengan pemilihan pekerjaan. Sebenarnya arti karier lebih luas dari sekedar memilih pekerjaan. Karier berkaitan dengan perkembangan seseorang dan menjadi bagian penting dalam kesuksesan hidup seseorang, untuk itu karier perlu direncanakan dengan baik. Kemampuan perencanaan karier yang matang erat kaitannya dengan pemahaman siswa mengenai karier itu sendiri. Suksesnya pencapaian karier seseorang dipengaruhi oleh adanya kemampuan perencanaan karier dan pengambilan keputusan yang matang. Seseorang yang memiliki kemampuan perencanaan karier, tentunya mampu memahami dirinya. Dengan demikian, individu tersebut dapat memutuskan pilihan yang paling tepat sesuai dengan keadaan dirinya.

Memilih pekerjaan serta merencanakan diri untuk karier yang akan dipilih tidak cukup hanya saran yang baik, itu tidak cukup bagi para peserta didik sebab mereka juga memiliki beberapa keterbatasan dalam perencanaan kariernya, yaitu (a) gagasan yang ditanamkan oleh keluarga dan masyarakat akan apa yang dianggap sebagai pilihan pekerjaan dan pendidikan yang tepat, (b) kenyataan ekonomi yang buruk sehingga menghambat mereka dalam mengikuti pendidikan yang mereka pilih, (c) kurangnya akses akan fasilitas pendidikan (ILO, 2011).

Menurut Winkel (2004), "perencanaan yang matang menuntut pemikiran tentang segala tujuan yang hendak dicapai dalam jangka panjang (longrange goals) dan semua tujuan yang hendak dicapai dalam jangka pendek (short-range goals)". Secara ideal, tujuan jangka pendek menjadi tujuan intermediar yang semakin mendekatkan siswa kepada tujuan jangka panjang. Gaya hidup (life style) yang ingin 
dicapai termasuk tujuan dalam jangka panjang misalnya, dan nilai-nilai kehidupan (values) yang ingin direalisasikan dalam hidup. Sertifikat, ijazah yang dipersiapkan untuk memegang suatu rencana pekerjaan di masa depan, termasuk tujuan dalam jangka pendek. Dalam merencanakan karier, terdapat berbagai faktor yang mempengaruhi. Faktor-faktor tersebut dapat berasal dari diri sendiri (internal) maupun dari luar diri sendiri (eksternal). Winkel (2004) mengemukakan bahwa faktor internal yang mempengaruhi perencanaan karier seseorang meliputi nilai-nilai kehidupan, taraf intelegensi, bakat khusus, minat, sifat-sifat, pengetahuan, dan keadaan jasmani.

Individu dalam usahanya untuk mencapai karir yang diinginkan sering mengalami hambatan, sehingga diperlukan usaha untuk mengatasi hambatan tersebut. Tingkat usaha untuk mengatasi hambatan dalam mencapai karir yang diinginkan dipengaruhi oleh locus of control. Locus of control merupakan keyakinan individu dalam memandang faktor penyebab keberhasilan maupun kegagalan yang dialami, termasuk hadiah dan hukuman yang diterimanya. Lefcourt (dalam Smet, 1994) menjelaskan bahwa locus of control mengacu pada derajat dimana individu memandang peristiwa-peristiwa dalam kehidupannya sebagai konsekuensi perbuatan-perbuatannya, dengan demikian dapat dikontrol (control internal), atau sebagai sesuatu yang tidak berhubungan dengan perilakunya sehingga di luar kontrol pribadinya (control eksternal).

Internal locus of control merupakan keyakinan di dalam diri individu bahwa pencapaian atau hasil yang datang pada dirinya merupakan efek dari usaha yang telah dilakukannya, artinya keberhasilan di dalam hidup individu ditentukan oleh dirinya sendiri, bukan di kontrol oleh lingkungan. Individu yang memiliki internal locus of control memiliki keyakinan bahwa dirinya dapat mengatur dan mengarahkan hidupnya serta bertanggungjawab terhadap pencapaian penguat apapun yang diterimanya.

Menurut Zulkaida (2007), individu dengan internal locus of control cenderung menganggap bahwa ketrampilan (skill), kemampuan (ability), dan usaha (efforts) lebih menentukan pencapaian dalam hidup, termasuk pencapaian karirnya. Individu akan mengembangkan usahanya untuk meningkatkan keterampilan kerja dan kemampuan akademik yang dimiliki dalam rangka meraih karir yang diinginkan, serta berusaha mengatasi hambatan yang dihadapi 
dalam rangka pencapaian karir. Individu yang mempunyai internal locus of control, ketika dihadapkan pada pemilihan karir, maka akan melakukan usaha untuk mengenali diri, mencari tahu tentang pekerjaan dan langkah-langkah pendidikan serta berusaha mengatasi masalah berkaitan dengan pemilihan karir.

Faktor lain selain locus of control yang dapat mempengaruhi perencanaan karir adalah efikasi diri. Efikasi diri merupakan salah satu faktor personal yang menjadi perantara atau mediator dalam interaksi antara faktor perilaku dan faktor lingkungan. Efikasi diri dapat menjadi penentu keberhasilan performansi dan pelaksanaan pekerjaan. Efikasi diri juga sangat mempengaruhi pola pikir, reaksi emosional, dalam membuat keputusan (Mujiadi, 2003).

Menurut Bandura (1977) efikasi diri adalah keyakinan seorang individu mengenai kemampuannya dalam mengorganisasi dan menyelesaikan suatu tugas yang diperlukan untuk mencapai hasil tertentu. Efikasi diri yakni keyakinan bahwa seseorang bisa menguasai situasi dan mendapatkan hasil positif. Bandura (Santrock, 2007) mengatakan bahwa efikasi diri berpengaruh besar terhadap perilaku. Orang yang memiliki efikasi diri yang tinggi akan memiliki keyakinan mengenai kemampuannya dalam mengorganisasi dan menyelesaikan suatu tugas yang diperlukan untuk mencapai hasil tertentu dalam berbagai bentuk dan tingkat kesulitan, sedangkan individu yang memiliki efikasi diri yang rendah akan memiliki keyakinan sebaliknya. Misalnya, seorang individu yang memiliki efikasi diri rendah mungkin tidak mau berusaha belajar untuk mengerjakan ujian karena tidak percaya bahwa belajar akan bisa membantunya mengerjakan soal.

Bandura (1977) mengemukakan beberapa dimensi dari efikasi diri, yaitu magnitude, generality, dan strength. Magnitude, berkaitan dengan tingkat kesulitan suatu tugas yang dilakukan. Generality, berkaitan dengan bidang tugas, seberapa luas individu mempunyai keyakinan dalam melaksanakan tugas-tugas. Strength, berkaitan dengan kuat lemahnya keyakinan seorang individu. Efikasi diri menurut Alwisol (2005) dapat diperoleh, diubah, ditingkatkan atau diturunkan, melalui salah satu atau kombinasi empat sumber, yakni pengalaman menguasai sesuatu prestasi (performance accomplishment), pengalaman vikarius (vicarious experiences), persuasi sosial (social persuation) dan pembangkitan emosi (emotional/ physiological states). Pengalaman performansi adalah prestasi 
yang pernah dicapai pada masa yang telah lalu. Pengalaman vikarius diperoleh melalui model sosial. Persuasi sosial adalah rasa percaya kepada pemberi persuasi, dan sifat realistik dari apa yang dipersuasikan.

Berdasarkan hasil studi pendahuluan dengan wawancara tersebut, diperoleh juga informasi dari hasil analisis Daftar Cek Masalah (DCM) bidang karier yang diberikan kepada mahasiswa Prodi Bimbingan dan Konseling IKIP PGRI MADIUN, diperoleh hasil sebanyak $64 \%$ memiliki masalah mengenai "saya tidak tahu berbuat apa setelah lulus". Berdasarkan hasil tersebut dapat diketahui bahwa mahasiswa Prodi Bimbingan dan Konseling IKIP PGRI MADIUN masih bingung merencanakan kariernya atau dapat diartikan mahasiswa memiliki perencanaan karier yang rendah. Dengan demikian, perlu dicari faktor yang mempengaruhi rendahnya perencanaan karir mahasiswa Prodi Bimbingan dan Konseling IKIP PGRI MADIUN. Hal ini dikarenakan karier merupakan suatu bagian hidup yang tidak dapat terpisahkan, perencanaan karier merupakan suatu hal yang hendaknya dilakukan sedini mungkin. Setidaknya mahasiswa memiliki gambaran dan rencana yang baik untuk masa depan yang sesuai yang diinginkan.
Berdasarkan pemaparan di atas, penulis merumuskan bahwa konsep perencanaan karir, internal locus of control dan efikasi diri pada mahasiswa prodi Bimbingan dan Konseling IKIP PGRI MADIUN ini perlu dikaji lebih lanjut. Pada penelitian ini, peneliti tertarik untuk mengkaji apakah terdapat hubungan yang positif antara internal locus of control dengan perencanaan karir dan mengkaji lebih dalam apakah terdapat hubungan yang positif antara efikasi diri dengan perencanaan karir.

\section{Metode Penelitian}

Penelitian termasuk jenis penelitian korelasional. Dilihat dari sifatnya, penelitian ini bersifat "expost-facto". Disebut penelitian "expost-facto" karena para peneliti berhubungan dengan variabel yang telah terjadi dan tidak perlu memberikan perlakuan terhadap variabel yang diteliti. Pada penelitian ini variabel bebas dan variabel terikat sudah dinyatakan secara eksplisit (Sugiyono, 2008).

Populasi dalam penelitian ini adalah mahasiswa Prodi Bimbingan dan Konseling IKIP PGRI Madiun, dengan jumlah populasi sebanyak 459 mahasiswa. Dari jumlah populasi sebanyak 459 mahasiswa diambil sampel sebanyak 210 mahasiswa. Sampel 
diambil secara acak (simple random sampling) tanpa memperhatikan strata yang ada dalam populasi tersebut.

Data dalam penelitian ini diperoleh melalui menggunakan skala penelitian. Skala penelitian terdiri dari tiga macam, yaitu skala efikasi diri, skala internal locus of control dan skala perencanaan karier. Masing-masing skala terdiri dari 20 aitem.

Skala efikasi diri dikembangkan berdasarkan aspek kognitif, motivasi, afeksi dan seleksi. Deskriptor aspek kognitif terdiri dari 1) Percaya diri dalam memikirkan caracara untuk mencapai tujuan, dan 2) Keraguan dalam merancang tindakan untuk mencapai tujuan. Deskriptor aspek motivasi terdiri dari 1) Kemampuan memotivasi diri dengan pikiran untuk melakukan tindakan, dan 2) Membuat keputusan untuk mencapai tujuan yang diharapkan. Deskriptor aspek afeksi adalah 1) Mampu mengatasi perasaan emosi yang muncul dari diri sendiri, dan 2) Mampu mengontrol kecemasan yang menghalangi dalam pikiran untuk mencapai tujuan. Sedangkan deskriptor aspek seleksi adalah 1) Mampu mempertimbangkan secara matang dalam memilih perilaku serta lingkungan, 2) Mampu mengendalikan aktivitas yang menantang, dan 3) menghindari situasi yang diyakini melebihi kemampuan yang mereka miliki.
Berdasarkan perhitungan uji validitas yang dilakukan pada data skala Efikasi Diri diperoleh hasil 20 aitem sahih dengan nilai $r$ hitung berkisar antara $0,518-0,858$ (taraf signifikansi 5\%). Hasil uji reliabilitas menghasilkan koefisien Alpha sebesar 0,950 , sehingga skala efikasi diri dianggap reliabel untuk digunakan dalam penelitian.

Skala internal locus of control disusun berdasarkan pada aspek afektif, kognitif dan psikomotorik. Deskriptor aspek afektif adalah memiliki inisiatif yang tinggi. Deskriptor aspek kognitif adalah 1) Selalu mencoba untuk berfikir seefektif mungkin, dan 2) Selalu mempunyai persepsi bahwa usaha harus dilakukan jika ingin berhasil. Deskriptor aspek psikomotorik adalah 1) Suka bekerja keras, dan 2) Selalu berusaha untuk menemukan pemecahan masalah.

Berdasarkan perhitungan uji validitas yang dilakukan pada data skala internal locus of control diperoleh hasil 6 aitem gugur, dan 14 aitem sahih dengan nilai $\mathrm{r}$ hitung berkisar antara 0,297 - 0,649 (taraf signifikansi 5\%). Hasil uji reliabilitas menghasilkan koefisien Alpha sebesar 0,829, sehingga skala internal locus of control dianggap reliabel untuk digunakan dalam penelitian.

Skala perencanaan karier disusun berdasarkan aspek kognitif, motivasi, dan 
psikomotorik. Deskriptor aspek kognitif meliputi 1) Mempunyai inisiatif, untuk mencari sebuah informasi, 2) Memiliki alternative pilihan pekerjaan. Deskriptor aspek motivasi meliputi 1) Memanfaatka waktu luang untuk menggali informasi, 2) Selalu mempunyai persepsi bahwa usaha harus dilakukan jika ingin berhasil. Deskriptor aspek psikomotorik 1) Selalu mencari cara untuk mendapatkan informasi, 2) Memanfaatkan berbagai media untuk menggali informasi.

Berdasarkan perhitungan uji validitas yang dilakukan pada data angket perencanaan karier diperoleh hasil 3 aitem gugur, dan 17 aitem sahih dengan nilai $\mathrm{r}$ hitung berkisar antara 0,277 - 0,650 (taraf signifikansi 5\%). Hasil uji reliabilitas menghasilkan koefisien Alpha sebesar 0,844, sehingga skala perencanaan karier dianggap reliabel untuk digunakan dalam penelitian.

\section{Hasil Penelitian}

Berdasarkan hasil analisis regresi ganda dengan program SPSS for Windows versi 16 diperoleh data sebagai berikut:

Tabel 1. Rangkuman Hasil Uji t Parsial dalam Analisis Regresi

\section{Coefficients $^{\mathrm{a}}$}

\begin{tabular}{|c|c|c|c|c|c|c|}
\hline \multirow{2}{*}{\multicolumn{2}{|c|}{ Model }} & \multicolumn{2}{|c|}{$\begin{array}{c}\text { Unstandardized } \\
\text { Coefficients }\end{array}$} & \multirow{2}{*}{$\begin{array}{l}\text { Standardized } \\
\text { Coefficients }\end{array}$} & \multirow[b]{2}{*}{$\mathrm{t}$} & \multirow[b]{2}{*}{ Sig. } \\
\hline & & B & Std. Error & & & \\
\hline \multirow[t]{3}{*}{1} & (Constant) & 23.089 & 10.651 & & 2.168 & .037 \\
\hline & SelfEfikasi & .168 & .195 & .137 & .863 & .394 \\
\hline & iLoC & .533 & .227 & .374 & 2.353 & .024 \\
\hline
\end{tabular}

a. Dependent Variable: PK

Berdasarkan pada uji t parsial untuk mengetahui pengaruh efikasi diri terhadap perencanaan karier diperoleh nilai t sebesar 0,137 dengan taraf signifikansi 0,394 ( $\mathrm{p}<$ 0,05; signifikan). Hal ini menunjukkan tidak ada pengaruh yang signifikan efikasi diri terhadap perencanaan karier.

Efikasi diri merepresentasikan sebuah keyakinan tentang kemampuan memecahkan masalah dan mencapai kesuksesan. Dalam 
pekerjaan, orang yang memiliki keyakinan terhadap kemampuannya untuk memecahkan masalah, muncul sebagai pemimpin, sementara yang tidak percaya terhadap kemampuan diri memperlihatkan keraguan dan membutuhkan nasehat dari orang lain (Reivich \& Shatte, 2002:42). Sementara itu sumber-sumber Self-Efficacy (Bandura, dalam Lazarus et.al., 1984) terdiri dari tiga yaitu pengalaman keberhasilan dan pencapaian prestasi, pengalaman orang lain dan persuasi verbal.

Pengalaman keberhasilan merupakan satu aspek yang penting dalam perencanaan karir. Pengalaman keberhasilan merupakan sumber ekspektasi efikasi diri yang penting karena berdasarkan pengalaman individu secara langsung. Selain pengalaman keberhasilan yang dialami oleh individu sendiri, efikasi diri dapat muncul berdasarkan pada kemampuan mengamati perilaku dan pengalaman orang lain sebagai proses belajar individu. Sugesti yang diperoleh dari orang lain tentang juga dapat menjadi sumber keyakinan individu dalam mengatasi masalah sebagai dasar perencanaan karir. Mahasiswa yang tidak mampu mengkolaborasikan ketiga sumbersumber efikasi diri dalam dirinya mengalami kesulitan dalam melakukan perencanaan karir.
Selanjutnya, uji $\mathrm{t}$ parsial untuk mengetahui pengaruh internal locus of control terhadap perencanaan karier diperoleh koefisien korelasi sebesar 0,374 dengan taraf signifikansi 0,024 ( $\mathrm{p}<0,05$; signifikan). Hal ini menunjukkan ada pengaruh signifikan internal locus of control terhadap perencanaan karier. Individu yang memiliki kecenderungan internal locus of control lebih mengutamakan usahanya sendiri dalam menghadapi sesuatu, dan memandang tinggi kemampuannya sendiri. Selain itu, orang dengan internal locus of control yang tinggi cenderung akan bekerja keras dan memiliki pandangan bahwa usaha yang dilakukannya akan berhasil. Mahasiswa yang mempunyai internal locus of control, ketika dihadapkan pada pemilihan karir, maka akan melakukan usaha untuk mengenali diri, mencari tahu tentang pekerjaan dan langkah-langkah pendidikan serta berusaha mengatasi masalah berkaitan dengan pemilihan karir sehingga mahasiswa mampu menentukan perencanaan karir sesuai dengan keadaan dirinya. 
Tabel 2. Hasil Uji Regresi Linier Berganda

ANOVA $^{\text {b }}$

\begin{tabular}{|c|c|c|c|c|c|}
\hline Model & $\begin{array}{l}\text { Sum of } \\
\text { Squares }\end{array}$ & df & Mean Square & $\mathrm{F}$ & Sig. \\
\hline $\begin{array}{l}\text { Regression } \\
\text { Residual } \\
\text { Total }\end{array}$ & $\begin{array}{c}57.832 \\
234.068 \\
291.900\end{array}$ & $\begin{array}{r}2 \\
37 \\
39\end{array}$ & $\begin{array}{r}28.916 \\
6.326\end{array}$ & 4.571 & $.017^{\mathrm{a}}$ \\
\hline
\end{tabular}

a. Predictors: (Constant), iLoC, SelfEfikasi

b. Dependent Variable: PK

Berdasarkan uji regresi linier berganda diperoleh skor $\mathrm{F}$ sebesar 4,571 dengan taraf signifikansi 0,017 ( $\mathrm{p}<0,05$; signifikan). Hal ini berarti bahwa ada pengaruh simultan efikasi diri dan internal locus of control terhadap perencanaan karier. Adanya keyakinan di dalam diri individu bahwa pencapaian atau hasil yang datang pada dirinya merupakan efek dari usaha yang telah dilakukannya, artinya perencanaan karir seseorang ditentukan oleh dirinya sendiri, bukan di kontrol oleh lingkungan. Tabel 3. Tingkat Pengaruh Variabel

\section{Model Summary}

\begin{tabular}{|l|r|r|r|r|}
\hline Model & \multicolumn{1}{|c|}{$\mathrm{R}$} & R Square & Adjusted R Square & \multicolumn{1}{c|}{$\begin{array}{c}\text { Std. Error of the } \\
\text { Estimate }\end{array}$} \\
\hline 1 & $.445^{\mathrm{a}}$ & .198 & .155 & 2.51519 \\
\hline
\end{tabular}

a. Predictors: (Constant), iLoC, SelfEfikasi

Berdasarkan pada uji tingkat pengaruh variabel diketahui bahwa nilai $\mathrm{R}$ square adalah 0,198 yang artinya $19,8 \%$ perencanaan karier dipengaruhi oleh efikasi diri dan internal locus of control. Sedangkan $80,2 \%$ dipengaruhi oleh variabel lainnya yang tidak dibahas dalam penelitian ini. Hal ini sejalan dengan yang dikemukakan oleh 
Winkel (2004) bahwa "ada beberapa faktor yang mempengaruhi pilihan karier seseorang yang diantaranya adalah faktor internal dan faktor eksternal". Faktor internal, yang meliputi nilai-nilai kehidupan, taraf intelegensi, bakat khusus, minat, sifat-sifat, pengetahuan, dan keadaan jasmani. Faktor eksternal, yang meliputi masyarakat, keadaan sosial ekonomi negara, status sosial ekonomi keluarga, pengaruh keluarga, pendidikan sekolah, pergaulan teman sebaya, dan tuntutan jabatan. Kunci bagi perencanaan yang matang dan keputusan yang bijaksana terletak dalam pengolahan informasi tentang diri sendiri dan tentang lingkungan hidupnya. Dengan kata lain, hanyalah individu yang memiliki informasi yang relevan dan menafsirkan maknanya bagi dirinya sendiri, dapat membuat pilihanpilihan yang dapat dipertanggungjawabkan.

Berdasarkan pada uraian hasil penelitian, peneliti menyampaikan saran sebagai berikut:

a. Diharapkan bagi mahasiswa dapat memanfaat hasil penelitian ini sebagai bahan pertimbangan dalam merencanakan karir. Selain itu mahasiswa dapat memahami faktorfaktor yang mempengaruhi perencanaan karier, diantaranya efikasi diri dan internal locus of control. b. Bagi peneliti lain dapat mempertimbangkan faktor-faktor lain yang dapat mempengaruhi perencanaan karier mahssiswa.

\section{DAFTAR PUSTAKA}

Alwisol. 2007. Psikologi Kepribadian. Malang : UMM Press.

Lazarus, Richard S \& Folkman, Susan. 1984. Stress Appraisal And Coping. New York: Spring Publishing Company

Mulyadi, W. 2011. Pengaruh Kemampuan Karyawan Terhadap Kinerja Karyawan pada Cabang Toko Top Fashion Cimahi. Jurnal kemampuan. Tersedia di jbptunikompp-gdl-widimulyad-26581-1unikom_w-r.pdf [diakses 25 Mei 2015]

Pengangguran di Indonesia Mencapai 7,24 Juta jiwa. 2014. Tersedia di http://bisniskeuangan.kompas.com/rea d/2014/11/05/BPS.Pengangguran.di.In donesia.Mencapai.7.24.Juta.Jiwa. diakses tanggal 20 Mei 2015

Press Bandura, A. 1997. Self Efficacy: The Exercise of Control. New York: Freemanand Company.

Reivich, K \& Shatte, A. 2002. The Resiliennce Skill For Overcaning life's Inervitable Obtacle. New York. Broad way Books

Santrock, J. W. 2007. Remaja, jilid 2 edisi ke-sebelas. Jakarta: Erlangga.

Sugiyono. 2008. Statistik Nonparametis untuk Penelitian. Bandung: Alfabeta

Winkel, W.S., \& Hastuti, S. 2004. Bimbingan Karir di Institusi Pendidikan. Jakarta: Media Abadi. 
Zulkaida, A, dkk. 2007. Pengaruh Locus of Control dan Efikasi Diri Terhadap Kematangan Karir Siswa Sekolah Menengah Atas (SMA). Proceeding
Pesat, 2, B1-B4. Available FTP: ejournal.gunadarma.ac.id, diakses 4 Desember 2008. 